\title{
Learner strategies and self-efficacy: making the connection
}

Article

Accepted Version

Graham, S. (2007) Learner strategies and self-efficacy: making the connection. Language Learning Journal, 35 (1). pp. 81-93. ISSN 1753-2167 doi:

https://doi.org/10.1080/09571730701315832 Available at https://centaur.reading.ac.uk/12562/

It is advisable to refer to the publisher's version if you intend to cite from the work. See Guidance on citing.

To link to this article DOI: http://dx.doi.org/10.1080/09571730701315832

Publisher: Taylor \& Francis

All outputs in CentAUR are protected by Intellectual Property Rights law, including copyright law. Copyright and IPR is retained by the creators or other copyright holders. Terms and conditions for use of this material are defined in the End User Agreement.

\section{www.reading.ac.uk/centaur}

\section{CentAUR}

Central Archive at the University of Reading

Reading's research outputs online 
Learner strategies and self-efficacy: making the connection

Suzanne Graham, University of Reading

This article reports on part of a larger study of the impact of strategy training in listening on learners of French, aged 16 to 17 . One aim of the project was to investigate whether such training might have a positive effect on the self-efficacy of learners, by helping them see the relationship between the strategies they employed and what they achieved. One group of learners, as well as receiving strategy training, also received detailed feedback on their listening strategy use and on the reflective diaries they were asked to keep, in order to draw their attention to the relationship between strategies and learning outcomes. Another group received strategy training without feedback or reflective diaries, while a comparison group received neither strategy training nor feedback. As a result of the training, there was some evidence that students who had received feedback had made the biggest gains in certain aspects of selfefficacy for listening; although their gains as compared to the nonfeedback group were not as great as had been anticipated. Reasons for this are discussed. The article concludes by suggesting changes in how teachers approach listening comprehension that may improve learners' view of themselves as listeners.

\section{Introduction}

The impetus for many studies of language learner strategies has been to uncover what distinguishes more effective learners from less effective ones. Such studies have increasingly shown that the employment of a range of metacognitive strategies is a particularly important characteristic of the 'good language learner' (see Graham, 1997; Macaro, 2001). At the same time, effective strategy use seems to be closely bound up with motivation (Oxford \& Nyikos, 1989), although it is not clear whether strategy use aids motivation, or the other way round.

This article addresses those aspects of motivation that concern learners' beliefs in themselves as learners, and whether these can be improved by a programme of strategy instruction. Positive self-beliefs seem to be especially important for what has been called 'motivational maintenance' (see Dörnyei \& Ottó, 2004)—persevering with language learning, even in the face of difficulties. 


\section{Background}

A useful framework for thinking about students' beliefs about themselves as learners can be found in the literature on general educational psychology. Paris and Winograd (1990) refer to 'metacognitive beliefs'beliefs about thinking and learning. They categorise these beliefs into four kinds, of which two will be outlined here. The first of these is agencylearners' beliefs about their own abilities and competences. An important aspect of this is 'self-efficacy', or the belief in one's ability to accomplish a task. Self-efficacy beliefs guide people's choices, efforts and degree of persistence with tasks. High levels of self-efficacy appear to be particularly important in maintaining motivation in the face of difficulties and failure (Bandura, 1995). Studies that have investigated self-efficacy in language learning have also found that learners with high levels of selfefficacy seem to have better control over and knowledge of effective learner strategies (Vogely, 1995; Victori, 1999; Yang, 1999).

Self-efficacy beliefs are a response to a question central to motivational behaviour: 'Can I do this task?' (see Pintrich \& De Groot, 1990, pp. 33-34). They reflect individuals' judgements of how capable they are of performing specific activities, rather than their judgements about 'who they are as people or how they feel about themselves in general' (Zimmerman, 1995, p. 203). As such, self-efficacy beliefs are contextdependent: one may have high self-efficacy for solving long-division problems, for example, but low self-efficacy for carrying out physics experiments. The construct also differs from perceived self-competence, which Bandura (1993, p.216) describes as being much less specific than self-efficacy, involving a more general appraisal of one's competence, such as might be ascertained from the response to the question 'How good are you at maths?' Such a question usually relates to perceived proficiency in the 'here-and-now', whereas self-efficacy refers to beliefs about expectations of future achievement.

Furthermore, self-efficacy beliefs appear to be more than just a reflection of the amount of skill one possesses and are believed to 'contribute to academic performance over and above actual ability' (Zimmerman, 1995, p. 213, citing Bandura, 1993). In other words, selfefficacy is needed for individuals to make the most of their abilities. In addition, having the skill and knowledge to achieve success in something (perhaps gaining a top grade in French at GCSE) is no guarantee that one will have a high sense of self-efficacy for it. Indeed, Graham (2004) found that when the GCSE grades that Year 11 students of French predicted for themselves were compared with those predicted by their teacher, the learners significantly underestimated what they would achieve. They thus displayed low levels of self-efficacy in spite of high ability. 
The second element of metacognitive beliefs in the framework of Paris and Winograd (1990) is instrumentality. This concerns learners' perceptions of the relationship between the learning strategies they employ on tasks and learning outcomes. As such, it is related to the notion of attributions, or the reasons learners give to explain perceived 'success' or 'failure'. Attributions are believed to play an important role in selfefficacy beliefs and motivation for language learning (Tremblay \& Gardner, 1995). The impact of attributions on these factors can be either positive ('adaptive') or negative ('maladaptive'). Learners who believe that their academic achievements (including 'failure') can be explained by factors within their control (such as how hard they tried or which strategies they employed) are likely to be motivated to attempt similar tasks again. They can change the amount of effort or the type of strategies they employ, and therefore the possibility of doing better remains open. Motivation is likely to be lower among learners who believe that their lack of success is caused by factors beyond their control, such as the difficulty of the tasks they are given, or what they perceive as their own supposed innate and unchangeable low ability. In recent years, several studies have suggested that learners in England tend to make negative or maladaptive attributions for doing less well in foreign languages, blaming such factors as task difficulty or 'low ability' (see Williams \& Burden, 1999; Graham, 2002, 2004; Williams et al., 2002). Graham (2006a) suggests that such a tendency is particularly acute in a skill such as listening comprehension, where the processes involved to learners to be seem inaccessible and uncontrollable. Attitudes towards listening expressed by learners in that study included a sense of passivity, whereby, however hard they 'tried' at listening, progress was likely to be limited. Few students were aware of any strategies they might employ to make the listening process easier, other than 'listening for key words', a strategy one student claimed had been suggested by her teacher. Yet, as Graham (1997) indicates, when students say that they listen for 'key words', they rarely mean listening for words that are crucial for comprehension. Instead they mean latching on to any words that they can understand, regardless of their usefulness for understanding the text. Having only one strategy for listening however, can lead to a sense of stagnation.

Promoting positive self-efficacy beliefs seems to be especially important in the context of MFL learning in England, where decreasing numbers of students opt to study a foreign language when they no longer have to. Graham (2004) reports that for many students, feeling that they lacked the ability to do well in AS French was an important reason why they decided not to take the subject post-16. Macaro (unpublished study) found that many Year 13 learners believed that foreign languages were 
more difficult than their other A-level subjects. Many students who start the first year of post-16 study of French do not go on to take the full advanced level examination, possibly because they feel that they will achieve a lower grade in French than for other subjects.

There is some evidence in the literature of general educational psychology that learners' metacognitive beliefs, including the attributions they use to explain success or failure, can be modified. Brophy (1998) explains how this is possible through activities and feedback that encourage learners to deal with difficulties and setbacks by 'retracing their steps to find their mistake or by analyzing the problem to find another approach'. Feedback is especially important in helping them to attribute their failures to 'insufficient effort, lack of information, or use of ineffective strategies rather than to lack of ability' (Brophy, 1998). This approach involves drawing learners' attention to the link between their strategy use and their learning outcomes - that is, it increases their sense of instrumentality, to use the terminology of Paris and Winograd (1990). The aim of the present study was to investigate how far the self-efficacy of Year 12 learners of French could be improved by a programme of strategy training which encouraged them to make these links.

\section{The present study Students}

The self-efficacy of Year 12 learners of French for listening was explored with a larger project (see Graham and Macaro, The Language Learning Journal, Volume 35, Number 2), which sought to improve the listening and writing of students in this age group through a programme of strategy instruction.

Three groups of students were involved: a comparison group, made up of students from four schools, who received no strategy training but just completed a range of tests; and two treatment groups, a 'high scaffolding' group (HS group, made up of students from five schools) and a 'low scaffolding group' (LS group, made up of students from five schools). Table 1 gives details of the numbers involved at the start and the end of the project. ${ }^{1}$

TABLE 1 here

\section{Method}

Assessing self-efficacy. Students' listening proficiency was assessed at the start and end of the project through a group listening test. A different test was used each time but they were judged to be of comparable difficulty. 
Each test was on the topic of holidays, and learners were asked to write down in English everything they had understood from four short passages. They were thus required to understand the passages in detail and also to identify a number of opinions expressed in each one. After each test, students completed a self-efficacy questionnaire. This asked them to indicate how sure they were on a scale from ' 0 ' (very unsure) to ' 100 ' (completely sure) that, if faced with similar listening passages, they could do the following:

1. Understand the gist

2. Understand details

3. Work out the meaning of unknown words

4. Understand opinions

The questionnaire was based on one used in a study by the National Capital Language Resource Center (2000) in the US, which investigated the relationship between language learning strategy use and self-efficacy. By asking students to say how confident they were about tackling a similar task in the future rather than asking them how well they thought they had actually done on the task, the questionnaire tried to capture the 'future' aspect of self-efficacy. The four areas were chosen as typical of the challenges that students at this level are faced with in listening.

At the end of the project, students completed a questionnaire which asked them to indicate their areas of greatest and least success in language learning and to give the most likely reasons for these perceived successes or failures. This sought to obtain some information about students' attributions which might further elucidate the data gathered on selfefficacy. Students were also asked to comment on how much they felt their listening had improved during the course of the project and how helpful they felt the strategy instruction had been in this respect.

\section{Aspects of the strategy training directed at improving self-efficacy and positive attributions}

Students in both the HS and LS groups received detailed instruction in a number of listening strategies (see Graham and Macaro, op. cit.). In addition, the HS groups were involved in activities that were intended to help them see the connection between the strategies they employed while listening and how well they listened, as described below.

Initial awareness-raising. At the start of the project, students in the HS group took part in a session which invited them to consider a number of statements about language learning made by other students (the statements were drawn from Graham, 2006b). They were asked to sort 
these statements into those which suggested that the student was in control of his or her learning, and those which suggested a lack of control. They then discussed as a group whether they felt in control of their language learning. This led into a presentation by the researchers on how strategy use can help students achieve this control, with example of the listening and writing strategies used by good language learners (drawn from Graham, 1997, and Macaro, 2001). Subsequently, over approximately six months, students completed a range of listening activities as part of their normal class work. These modelled different listening strategies. At the end of each activity, learners were asked to indicate which strategies they had used and which they felt had been most useful.

The strategy training for LS students differed in that it did not start with an awareness-raising session. Thus, there was less emphasis for these students on how the strategies that were later presented in class activities would increase their control over their learning. The activities LS students completed in class were, however, the same as those carried out by the HS schools.

Reflection and strategy feedback. Additional measures were taken with the HS group, in order to increase their sense that the strategies they were being taught and were using were increasing their control over their ability to listen effectively. After they had completed the listening strategy training activities and indicated which strategies they had used, students from this group were asked to submit their work to the researchers, who then provided feedback on their strategy use only. Feedback on the correctness of their answer was only given in relation to the strategy use associated with it. For example, if a learner incorrectly wrote that a listening text had said that grandparents should spend more time with their grandchildren, while the text had in fact said that a number of people are affected when parents divorce, including grandparents, the learner would be advised that he or she needed to verify any predictions made before hearing the text by listening carefully for any disconfirming statements, and to rely less on what common sense suggested.

Learners in the HS group were also asked to keep a strategy use log, a kind of reflective diary. This asked them to comment on the listening strategies they thought they had used during the month, under the headings of 'Preparation for listening', 'Process of listening', and 'Checking/monitoring'. They then listed their plans for developing strategies during the next month and how they were going to achieve this. In addition, they were asked to comment on their progress in listening using the following headings:

- What went well? 
- Why?

- What didn't go well?

- Why?

- What do I feel?

- What next?

The purpose of this was to draw students' attention to the link between what they did (i.e. the strategies they used) and how well the listening task had gone, and to get them thinking about what strategies they might try out in the future to further improve their learning. In essence, the aim was to try to modify learners' meta- cognitive beliefs and the attributions they made for doing well and not so well. Students submitted their logs to the researchers, who then sought to underline this connection between strategies and outcomes in the feedback they gave to students. When students tried to attribute their learning outcomes to things other than strategies, such as the speed of the tape or the difficulty of the task, the researchers tried to show in their feedback how a different strategy might help them cope with these aspects. Here is an example of the sort of dialogue that was thus established: Student $\mathrm{C}$ has commented that listening is difficult and that it is difficult to make progress. The researcher tries to help her see what she could do to change this situation:

Feedback to Student C:

Thank you very much for your thoughtful comments. It is encouraging to see that you are using some important strategies. Listening is difficult and it can seem as if it is hard to make progress. But looking at your diary and at your work over the months, it's clear to me that the strategies you are using are helping you to improve, even if you still don't feel totally confident. It will take time.

I'm glad to see you are reading accompanying questions and blurb to get an overall sense of the passage before you startthat's important, so that you don't get bogged down by detail too soon. Try to think quite broadly at first about what you might hear, especially for the first listening - and remember that you might not hear the exact word you have predicted, but a synonym for it or a phrase. 
Checking and monitoring are important too-so, for example, if you predict what words/ideas you might hear, you also need to listen out for things like negatives that tell you that your predictions weren't quite right. If you predict individual words, listening to what comes before and after them can help you check out your predictions too.

Well done-I look forward to reading what you say for next month's entry.

Student $\mathrm{R}$ suggests in her diary that she has done better in listening because she feels the class has been given easier work recently. The feedback aims to help her see that it is what she has done, rather than the nature of the tasks, that may well have helped in this respect.

Feedback to Student R:

You have made some very thoughtful comments and it's great to see that you feel you are making progress. Don't just assume that you have done better on a listening because it is slower-it may be that you are getting better at dealing with the speed of passages because of the strategies you are using, to break up the text, for example. The strategies you list on the second sheetlistening for discourse markers, tone of voice, anticipating what might come up, will all have helped with this.

The amount of feedback individual students received varied greatly, however, as it was dependent on how many pieces of work they submitted and how many diary entries they made. Generally, students completed far fewer strategy logs than the project team had originally hoped, and some teachers reported that students particularly disliked this aspect of the project. The teacher who seemed to have the most success in persuading her students to complete the logs did so by giving them time in lessons for this.

Students in the LS group did not keep reflective diaries and did not receive feedback on their strategy use from the researchers.

\section{Results}

In terms of the impact the strategy instruction had on the students' listening scores between pre- and post-test, the results were encouraging, 
with HS schools making the most improvement out of all three groups. ${ }^{2}$

As far as self-efficacy for listening is concerned, most students displayed low levels (Table 2) at the beginning of the project, particularly regarding understanding detail and unknown words. In the normal course of events, we might expect that by post- test, all students would have gained more confidence in their listening ability, simply from having been exposed to more French during the course of six to eight months. This was indeed the case (see Tables 3 and 4). The HS schools made the greatest gains in all aspects of self-efficacy for listening, followed by the LS schools. Statistical tests ${ }^{3}$ indicated that HS and LS schools' gains were significantly greater on understanding detail and understanding opinions than those of the comparison schools. No statistically significant difference was found between the HS and LS gain scores, however.

\section{TABLS 2-4 here}

These gains suggest that the strategy instruction had the biggest impact on HS and LS students' confidence in understanding details and opinions. These areas are particularly important for listening at AS and A2 level, and many of the strategies included in the instruction were aimed at helping students to be more careful in their listening, verifying their predictions and paying attention to features such as negatives and discourse markers used in the texts.

The above results need to be interpreted with caution, however. It is possible that the greater gains in self-efficacy for the HS group were influenced by the fact that at pre-test they had significantly lower levels of self-efficacy for listening than the comparison schools on understanding details and understanding unknown words. ${ }^{4}$ Hence the HS schools seem to have made the most gains in self-efficacy partly because they had the most ground to make up.

The extent to which self-efficacy for listening improved also differed between schools and individuals. As explained above, some schools received more feedback than others, simply because they submitted more work and strategy sheets than others. For example, in one school, most students received between five and seven pieces of feedback over six months. In another, by contrast, the most any student received was two pieces.

One student, who received seven pieces of feedback over six months, is of interest because of the way he seemed to engage with the project and to be able to perceive the links between how he was listening and his achievements in that area. At pre-test, he had high levels of self-efficacy 
in most areas of listening, except for understanding unknown words. By post-test, his self-efficacy had improved in all areas except for understanding gist (already very high at pre-test), and especially in understanding unknown words. He (along with a classmate) received the greatest number of pieces of feedback in the project. Just after the post-test he completed an individual listening task which required him to report on the listening strategies he was using. Space does not permit a full analysis of this interview, but it was clear that he was using many of the strategies introduced during the project. At the end of the interview he was asked if he thought that how he listened had changed over the last six to seven months, to which he replied: 'I think my methods have changed really, the way I approach it. I sort of get in the right frame of mind to do it.... If something's difficult, I don't sort of like panic about it...'

This suggests a greater perseverance in the face of difficulty and a confidence that such difficulties can be overcome through the application of appropriate strategies. This student seemed to have appreciated the strategy training and to have benefited from it. The questionnaire data gathered at the end of the project indicated, however,that most students were not entirely positive about how helpful the training had been. Using a scale from ' 1 ' ('not at all helpful') to ' 6 ' ('very helpful'), $47 \%$ of respondents gave a rating for the training of ' 4 ' or over. Nevertheless, when the responses of the HS students were compared with those of LS students, the former were more likely to rate the training more highly. ${ }^{5}$ In terms of how students perceived their success in listening at the end of the project, again, results are mixed. On the one hand, as Graham (2002) found for a similar cohort of learners, students in all three groups (HS, LS and comparison) claimed that listening was the area in which they felt they had achieved the least success. The most common reasons for this lack of success, for all students, was perceived low ability and difficult tasks. This suggests that the feedback had not succeeded in drawing HS learners' attention to the link between strategy use and achievement. However, the numbers of learners involved are very small (10 HS students). It may also be the case that changing learners' attributional tendencies takes longer than six to eight months. More encouraging was the finding that HS learners felt that their listening had improved more than LS or CS learners did. ${ }^{6}$

\section{Discussion}

The above analysis suggests that there is some evidence that strategy training had a beneficial impact on students' self-efficacy for listening, as well as on their actual listening achievement, as measured by the comprehension tests used in the study. It is not possible, however, to 
clarify exactly the relationship between gains in listening achievement and gains in self-efficacy for listening. It may be that students felt more confident about their listening because they were able to understand more of the post- test passages; or that their increased self-efficacy for listening contributed to their ability to comprehend.

However, the differences between the LS and HS schools in terms of improved self-efficacy were smaller than expected. This lack of difference may be because HS students as a whole did not receive enough feedback on their strategy use for this form of scaffolding to have a significant impact on their self-efficacy. Both LS and HS students were asked to reflect on their strategy use at the end of each activity in the programme, in order to evaluate the effectiveness of the strategies employed. It may be that this provided both groups with similar opportunities to reflect on the connections between the strategies they used and how well they performed on the listening task. In other words, there may not have been enough substantive difference between the training received by the two groups for there to be significant differences in their self-efficacy gains. On the other hand, HS learners were more aware of an improvement in their listening than were LS learners.

There is thus some, if tentative, evidence that strategy instruction with feedback that focuses on the relationship between strategy deployment and successful listening is a promising method for improving both listening performance and students' deep- seated feelings about listening. Giving such feedback, however, is time-consuming and requires a detailed understanding on the part of the person giving the feedback of what strategies students appear to be using. It also requires students to develop a reflective stance towards their work, to think about the strategies they have used on an activity. Some learners find this task easier than others.

\section{Pedagogical implications}

The results of this study suggest that one way of improving learners' sense of self- efficacy for listening is for the process of listening to be considered to be as important as the product, if not more so. In other words, both learners and teachers need to be focused on how learners are listening rather on just what they have or have not understood from a passage. An important first step in this direction might be provided by activities that simply raise students' awareness of the fact that strategies for listening do exist, and that these can make the listening process easier and more successful. This might involve the teacher in asking learners to reflect on what difficulties they experienced with a listening text and to 
discuss as a group ways of overcoming those difficulties, other than simply knowing more vocabulary or listening repeatedly. At this point teachers might also suggest strategies for learners to try. To be able to do this effectively, teachers will need to have considered in advance what difficulties learners might encounter, and what might be useful strategies to use in response to these problems, in the way suggested by Graham and Macaro (op. cit.). The next step would be to ask learners in subsequent listening tasks to reflect on the listening strategies they have used and the impact they have had on their listening outcomes, perhaps employing the diary format used in the present study. Making such reflection part of the teacher's expectations for a homework or class listening task may help in encouraging students to take the process of reflection seriously. Teacher feedback on the strategies used by learners would also help in this respect, as well as encouraging learners to see listening as an activity in which improvement is possible through action taken by the listener, rather than as an activity in which they are just a passive recipient.

The above measures, it is argued, may increase learners' sense of control over the listening process, and in turn strengthen their resolve to persevere in the face of difficulties.

Notes

1. The project also involved tests completed at the start of Year 13, designed to see whether any gains made by HS and LS schools had been maintained. At the time of writing, these data were still being processed and therefore not available for inclusion in this article.

2. Space does not permit full statistical details of students' improvement in listening, which will appear in subsequent publications.

3. The Mann-Whitney U-test was employed to test for significant differences. This non-parametric test was employed as the data from the self-efficacy scale were ordinal rather than interval. Full statistical details are available from the author.

4. When an ANCOVA was carried out that took into account the groups' pre-test levels of self- efficacy, the significant differences in gains between the groups were no longer evident, although the difference between HS and comparison schools for understanding detail approached significance $(\mathrm{p}=.067)$. 
5. Mann-Whitney U-test. Full statistical details are available from the author.

6. Mann-Whitney U-test. Full statistical details are available from the author.

\section{References}

$\underline{\text { References }}$

Bandura, A. (1986). Social foundations of thought and action : A social cognitive theory. Englewood Cliffs, N.J.: Prentice-Hall.

Bandura, A. (1993). Perceived self-efficacy in cognitive development and functioning. Educational Psychologist, 28, 117-148.

Bandura, A. (1995). Exercise of personal and collective efficacy in changing societies. In: A. Bandura, (Ed.), Self-efficacy in changing societies (pp. 1-45). Cambridge: Cambridge University Press.

Brophy, J. (1998). Failure syndrome students. ERIC Digest Report No: EDO-PS-98-2. Available at: http://www.firstsearch.oclc.org

Dörnyei, Z., \& Ottó, I. (2004). Motivation in action: A process model of L2 motivation [online]. CILT Research Forum- Motivation in Language Learning. Available at: http://www.cilt.org.uk/research/resfor3/dornyei.htm

Graham, S. (1997). Effective language learning. Positive strategies for advanced level language learning. Clevedon, England: Multilingual Matters.

Graham, S. (2002). Experiences of learning French: A snapshot at years 11, 12 and 13. Language Learning Journal, 25, 15-20.

Graham, S. (2004). Giving up on Modern Foreign Languages? Students' perceptions of learning French. Modern Language Journal, 88/2, 171-191.

Graham, S. (forthcoming, a). Listening comprehension: the learners' perspective. System, 34/2.

Graham, S. (forthcoming, b). A study of students' metacognitive beliefs about foreign language study and their impact on learning. Foreign Language Annals

Macaro, E. (2001). Learning strategies in foreign and second language classrooms. London: Continuum.

National Capital Language Resource Center. (2000). High School Foreign Language Students' Perceptions of Language Learning Strategies Use and Self-Efficacy. (Washington, DC, Department of Education). 
Oxford, R. \& Nyikos,M. (1989). Variables affecting choice of language learning strategies by university students. Modern Language Journal, 73, 291-300.

Paris, S. G., \& Winograd, P. (1990). How metacognition can promote academic learning and instruction. In: B. F. Jones \& L. Idol (Eds.), Dimensions of Thinking and Cognitive Instruction (pp.15-51). Hillsdale NJ: Erlbaum.

Pintrich, P.R \& De Groot, E.V. (1990). Motivational and self-regulated learning components of classroom academic performance. Journal of Educational Psychology, 82(1), 33-40.

Tremblay, P. F., \& Gardner, R. C. (1995). Expanding the motivation construct in language learning. Modern Language Journal, 79, 505-520.

Victori, M. (1999). An analysis of writing knowledge in EFL composing: A case study of two effective and two less effective writers. System, 27(4), 537-555.

Vogely, M.(1995). Perceived strategy use during performance on three authentic listening comprehension tasks. Modern Language Journal, 79(1), 41-46.

Williams, M., \& Burden, R. (1999). Students' developing conceptions of themselves as language learners. Modern Language Journal, 83, 193-201. 
Table 1

Numbers of students completing self-efficacy questionnaire at pre- and post-test.

\begin{tabular}{|l|l|l|}
\hline & \multicolumn{1}{|c|}{ Pre-test } & \multicolumn{1}{c|}{ Post-test } \\
\hline Comparison group & 50 & 46 \\
\hline High scaffolding group & 35 & 32 \\
\hline Low scaffolding group & 54 & 40 \\
\hline
\end{tabular}


Table 2.

Pre-test self-efficacy. Number and percentage (in brackets) of students expressing different levels of certainty about being able to understand certain aspects of texts.

\begin{tabular}{|c|c|c|c|c|c|c|c|c|c|c|c|c|}
\hline & \multicolumn{3}{|c|}{$\begin{array}{l}\text { Comparison group } \\
\end{array}$} & \multicolumn{3}{|c|}{\begin{tabular}{l|l} 
& High Scaffolding group \\
\end{tabular}} & \multicolumn{4}{|c|}{\begin{tabular}{l|l|} 
& Low Scaffolding group \\
\end{tabular}} & \multicolumn{2}{|c|}{ All } \\
\hline $\begin{array}{l}\text { Level of } \\
\text { certainty } \\
\text { about being } \\
\text { able to } \\
\text { understand a } \\
\text { similar text }\end{array}$ & $\begin{array}{l}\text { Unsure } \\
(0-40 \% \\
\text { level) }\end{array}$ & \begin{tabular}{|l|} 
Fairly \\
sure \\
$(50 \%$ \\
level)
\end{tabular} & $\begin{array}{l}\text { Sure } \\
(60- \\
100 \% \\
\text { level })\end{array}$ & $\begin{array}{l}\text { Unsure } \\
(0-40 \% \\
\text { level) }\end{array}$ & $\begin{array}{l}\begin{array}{l}\text { Fairly } \\
\text { sure }\end{array} \\
(50 \% \\
\text { level) }\end{array}$ & \begin{tabular}{|l|}
$\begin{array}{l}\text { Sure } \\
(60-\end{array}$ \\
$100 \%$ \\
level)
\end{tabular} & $\begin{array}{l}\text { Unsure } \\
(0-40 \% \\
\text { level) }\end{array}$ & \begin{tabular}{|l|} 
Fairly \\
sure \\
$(50 \%$ \\
level)
\end{tabular} & $\begin{array}{l}\begin{array}{l}\text { Sure } \\
(60-\end{array} \\
100 \% \\
\text { level) }\end{array}$ & $\begin{array}{l}\text { Unsure } \\
(0-40 \% \\
\text { level })\end{array}$ & $\begin{array}{l}\text { Fairly } \\
\text { sure } \\
(\mathbf{5 0 \%} \\
\text { level) }\end{array}$ & $\begin{array}{l}\text { Sure } \\
(60- \\
100 \% \\
\text { level) }\end{array}$ \\
\hline Gist & $18(36)$ & $13(26)$ & $19(38)$ & $17(49)$ & $5(14)$ & $13(37)$ & $18(33)$ & $13(24)$ & $23(43)$ & $53(38)$ & $31(22)$ & $55(40)$ \\
\hline Details & $28(56)$ & $13(26)$ & $9(18)$ & $25(71)$ & $6(17)$ & $4(11)$ & $33(61)$ & $14(26)$ & $7(13)$ & $86(62)$ & $33(24)$ & $20(14)$ \\
\hline $\begin{array}{l}\text { Unknown } \\
\text { words }\end{array}$ & $39(78)$ & $4(8)$ & $7(14)$ & $33(94)$ & $2(6)$ & $0(0)$ & $50(93)$ & $1(2)$ & $3(5)$ & $\begin{array}{l}122 \\
(88)\end{array}$ & $7(5)$ & $10(7)$ \\
\hline Opinions & $13(26)$ & $14(28)$ & $23(46)$ & $15(43)$ & $6(17)$ & $14(40)$ & $11(20)$ & $16(30)$ & $27(50)$ & $39(28)$ & $36(26)$ & $64(46)$ \\
\hline
\end{tabular}


Table 3

Post-test self-efficacy. Number and percentage (in brackets) of students expressing different levels of certainty about being able to understand certain aspects of texts.

\begin{tabular}{|c|c|c|c|c|c|c|c|c|c|c|c|c|}
\hline & Compari & on group & & High Sca & folding & & Low Sca & olding gr & & All & & \\
\hline $\begin{array}{l}\text { Level of } \\
\text { certainty } \\
\text { about } \\
\text { being able } \\
\text { to } \\
\text { understan } \\
\text { d a similar } \\
\text { text }\end{array}$ & $\begin{array}{l}\text { Unsure } \\
(0-40 \% \\
\text { level) }\end{array}$ & $\begin{array}{l}\text { Fairly } \\
\text { sure } \\
\text { (50\% } \\
\text { level) }\end{array}$ & $\begin{array}{l}\text { Sure } \\
(60- \\
100 \% \\
\text { level })\end{array}$ & $\begin{array}{l}\text { Unsure } \\
(0-40 \% \\
\text { level) }\end{array}$ & $\begin{array}{l}\text { Fairly } \\
\text { sure } \\
(50 \% \\
\text { level) }\end{array}$ & $\begin{array}{l}\text { Sure } \\
(60- \\
100 \% \\
\text { level })\end{array}$ & $\begin{array}{l}\text { Unsure } \\
(0-40 \% \\
\text { level) }\end{array}$ & $\begin{array}{l}\text { Fairly } \\
\text { sure } \\
(50 \% \\
\text { level) }\end{array}$ & $\begin{array}{l}\text { Sure } \\
(60- \\
100 \% \\
\text { level) }\end{array}$ & $\begin{array}{l}\text { Unsure } \\
(0-40 \% \\
\text { level) }\end{array}$ & $\begin{array}{l}\text { Fairly } \\
\text { sure } \\
(\mathbf{5 0 \%} \\
\text { level })\end{array}$ & $\begin{array}{l}\text { Sure } \\
(60- \\
100 \% \\
\text { level })\end{array}$ \\
\hline Gist & $6(13)$ & $11(24)$ & $29(63)$ & $5(16)$ & $3(9)$ & $24(75)$ & $3(8)$ & $9(23)$ & $28(70)$ & $14(12)$ & $23(19)$ & $81(69)$ \\
\hline Detail & $20(43)$ & $10(22)$ & $16(35)$ & $13(41)$ & $7(22)$ & $12(38)$ & $13(33)$ & $12(30)$ & $15(38)$ & $46(39)$ & $29(25)$ & $43(36)$ \\
\hline $\begin{array}{l}\text { Unknown } \\
\text { words }\end{array}$ & 27 (59) & $8(17)$ & $11(24)$ & $24(75)$ & $3(9)$ & $5(16)$ & $25(63)$ & $9(23)$ & $6(15)$ & $76(64)$ & $20(17)$ & $22(19)$ \\
\hline Opinions & $10(22)$ & $13(28)$ & $23(50)$ & $3(9)$ & $7(22)$ & $22(69)$ & $1(3)$ & $6(15)$ & $33(83)$ & $14(12)$ & $26(22)$ & $78(66)$ \\
\hline
\end{tabular}


Table 4 Mean gains in self-efficacy between pre- and post-test

\begin{tabular}{|l|l|l|l|}
\hline $\begin{array}{l}\text { Self-efficacy for } \\
\text { understanding: }\end{array}$ & Comparison group & High Scaffolding group & Low Scaffolding group \\
\hline Gist & 8.9 & 16.0 & 12.4 \\
\hline Detail & 3.5 & 14.1 & 13.3 \\
\hline Unknown words & 7.3 & 15.2 & 13.1 \\
\hline Opinions & 3.0 & 16.4 & 10.0 \\
\hline
\end{tabular}

